J. WARZOCHA, J. GOSTKOWSKA

SEASONAL CHANGES OF MACROFAUNA IN THE GULF OF GDAŃSK

Sea Fisheries Institute, Gdynia, Poland

\begin{abstract}
Samples of macrofauna were taken with an $0.1 \mathrm{~m}^{2}$ van Veen grab at a $35 \mathrm{~m}$ deep muddy bottom in the Gulf of Gdańsk. Based on data collected 18 times between February 1987 and January 1988 , species composition, abundance, biomass, production, and size structure were analyzed. The macrofauna community was dominated by Macoma balthica which contributed about $98 \%$ of total biomass (dry weight). The highest abundance (maximum of 3509 ind. $/ \mathrm{m}^{2}$ ) occurred in autumn, whereas the biomass was rather stable throughout the year (mean of $259 \mathrm{~g}$ wet weight $/ \mathrm{m}^{2}$ ).
\end{abstract}

\title{
INTRODUCTION
}

The soft bottom fauna in the Gulf of Gdańsk has often been a subject of study, but the interest has been focused mostly on distribution of the fauna, with less information provided on seasonal variability (Kopacz and Wiktor 1986; Ostrowski 1976; Wenne and Wiktor 1982).

The aim of the present work was to assess seasonal changes of abundance, biomass, and size structure of the macrofauna, with a particular reference to the dominant species.

\section{AREA OF STUDY}

Samples of the bottom fauna collected at the station studied represent the macrofaunal community inhabiting the soft bottom of the Gulf of Gdansk below the depth of 10-30 $\mathrm{m}$ (Warzocha 1987). Bottom in the area of study was covered with mud containing about $7 \%$ of organic matter. Salinity and oxygen content in the near-bottom waters were stable throughout the year, the respective ranges being $7.7-8.0 \%$ and $8.7-9.54 \mathrm{ml} / \mathrm{dm}^{3}$. Temperature changed from $-0.3^{\circ} \mathrm{C}$ in February 1987 to $14^{\circ} \mathrm{C}$ in September and $3^{\circ} \mathrm{C}$ in January 1988 (data supplied by the Hydrology Laboratory, Sea Fisheries Institute). 


\section{MATERIALS AND METHODS}

Macrofaunal samples were collected between February 1987 and January 1988 at a $35 \mathrm{~m}$ deep station in the Gulf of Gdańsk (Fig. 1) on a total of 18 sampling occasions.

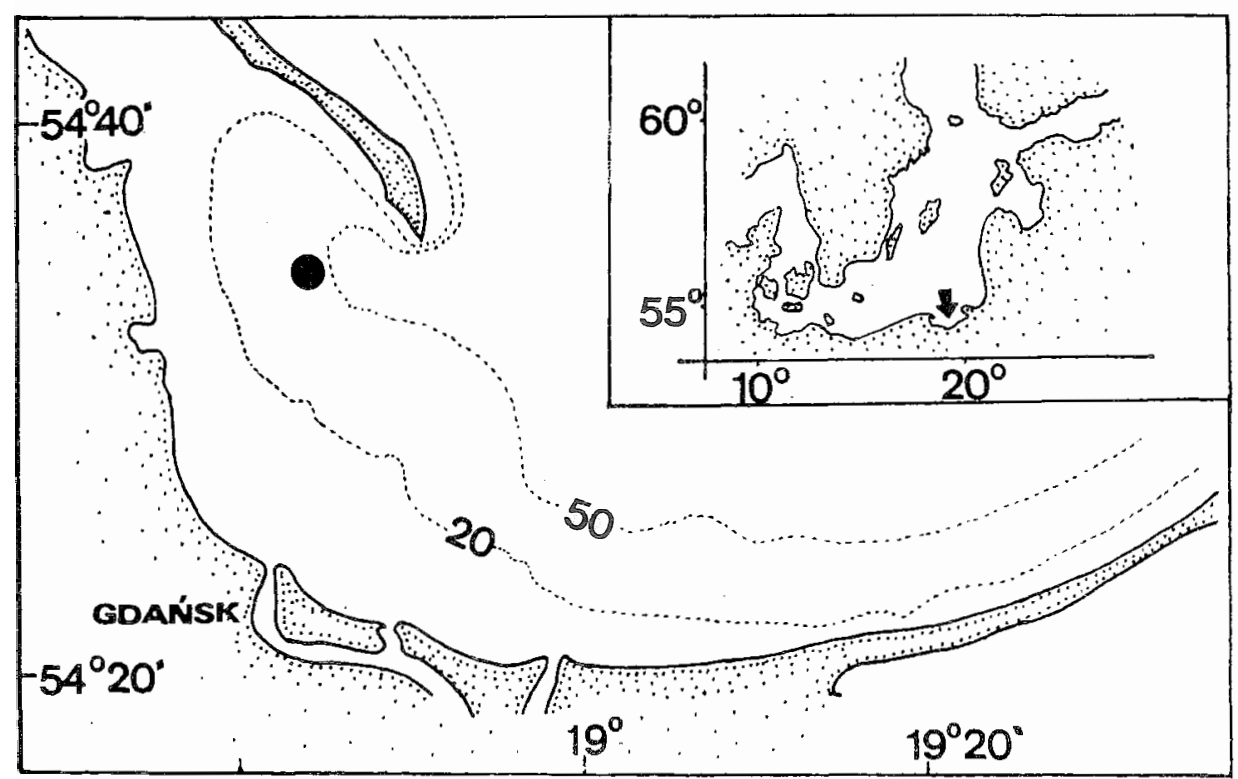

Fig. 1. Location of study area and sampling station

Three replicate samples were collected at the station with an $0.1 \mathrm{~m}^{2}$ van Veen grab. The content of the grab was sieved through a $1.0 \mathrm{~mm}$ mesh size sieve and the residue preserved in $10 \%$ buffered formalin.

In the laboratory, the animals were sorted, identified, and counted. Biomass was determined by direct weighing after blotting on a filter paper, and expressed as wet and dry weight. The biomass of Macoma balthica was calculated using the following length-weight relationships determined in May 1987:

$$
\log _{10} W=b \cdot \log _{10} L+a
$$

where: $\mathrm{W}=$ weight $(\mathrm{mg}) ; \mathrm{L}=$ maximum shell length $(\mathrm{mm}) ; \mathrm{r}=$ correlation coefficient 


\begin{tabular}{lcccc}
\hline & b & a & r & N \\
$\begin{array}{lcccc}\text { wet weight } \\
\text { including shells: }\end{array}$ & 2.92 & -3.74 & 0.98 & 77 \\
$\quad$ excluding shells: & 2.98 & -4.08 & 0.98 & 44 \\
$\begin{array}{c}\text { dry weight } \\
\text { including shells: }\end{array}$ & & & & \\
excluding shells: & 2.92 & -4.01 & 0.98 & 56 \\
& 2.89 & -4.72 & 0.97 & 44
\end{tabular}

The equations determining shell-free wet and dry weights were calculated for the length range of $4.0-22.0 \mathrm{~mm}$ and assumed to be valid also for specimens smaller than $4.0 \mathrm{~mm}$.

Diversity was calculated by means of the Shannon-Wiener formula (Pielou 1975): $H^{\prime}=-\Sigma p_{i} \ln p_{i}$, where $p_{i}$ is the proportion of the ith taxon.

The annual production was estimated using production to biomass ratios or number of generations per year and life-cycle turnover ratios available in the literature (Ankar and Elmgren 1976; Arntz 1971; Ostrowski 1976; Waters 1989). Energy contents of macrobenthic invertebrates were determined using published conversion factors (Brey et al. 1988).

Statistical treatment of data involved testing for significance of differences in abundance and biomass between seasons by means of the 1-way analysis of variance (ANOVA; Sokal and Rohlf 1981).

\section{RESULTS AND DISCUSSION}

A total of 10 macrobenthic taxa were found in the samples collected, Macoma balthica, Halicryptus spinulosus, Mesidotea entomon, and Pontoporeia femorata only occurring regularly throughout the period of study. Fluctuations in faunal composition, with regard to rare species, resulted most likely from irregular distribution patterns of those species, but seasonal migrations connected with changes in water temperature were also possible (Żmudziński 1966).

The fauna was strongly dominated by M. balthica which contributed $98 \%$ to the total biomass (dry weight). The composition and mean annual values of the community structure parameters used are presented in Table 1. A low diversity, exceptionally strong domination of a single species, and a high biomass were characteristic features of the community investigated, compared with other areas of the Southern Baltic (Warzocha 1987).

Results of the 1-way ANOVA (Table 2) showed significant changes in total abundance to have taken place during the period of study (Fig. 2). 
Table 1

Mean annual values of abundance, biomass (wet and dry weight, including shells of $M$. balthica) and diversity index $( \pm S D)$, of macrofauna at sampling station

\begin{tabular}{|l|r|r|r|}
\hline \multirow{2}{*}{ TAXON } & \multicolumn{2}{|c|}{$\begin{array}{c}\text { Abundance } \\
\left.\text { (ind } / \mathrm{m}^{2}\right)\end{array}$} & Biomass $\left(\mathrm{g} / \mathrm{m}^{2}\right)$ \\
& $72 \pm 156$ & $0.08 \pm 0.15$ & $0.01 \pm 0.01$ \\
Oligochaeta & $8 \pm 11$ & $0.04 \pm 0.01$ & $0.01 \pm 0.01$ \\
Hormothoe sarsi & $24 \pm 22$ & $2.74 \pm 2.24$ & $0.35 \pm 0.28$ \\
Halicryptus spinulosus & $962 \pm 621$ & $246.21 \pm 48.70$ & $142.85 \pm 26.27$ \\
Macoma balthica & $10 \pm 9$ & $7.01 \pm 7.35$ & $2.03 \pm 2.03$ \\
Mesidotea entomon & $290 \pm 176$ & $2.75 \pm 1.09$ & $0.52 \pm 0.22$ \\
Pontoporeia femorato & $31 \pm 11$ & $0.30 \pm 0.16$ & $0.03 \pm 0.01$ \\
Others & & & \\
& $1397 \pm 1006$ & $258.9 \pm 59.70$ & $145.80 \pm 28.83$ \\
\hline TOTAL & & & \\
\hline
\end{tabular}

Mean number of taxa per sample: $6.41 \pm 2.28$

Mean diversity $\left(H^{\prime}\right): \quad 1.03 \pm 0.21$

Table 2

Analysis of variance tables

\begin{tabular}{|c|c|c|c|c|c|c|}
\hline $\begin{array}{c}\text { Parameter } \\
\text { tested }\end{array}$ & $\begin{array}{l}\text { Source of } \\
\text { variation }\end{array}$ & $\begin{array}{l}\text { Degrees of } \\
\text { freedom }\end{array}$ & $\begin{array}{l}\text { Sum of } \\
\text { squares }\end{array}$ & $\begin{array}{l}\text { Mean } \\
\text { square }\end{array}$ & $\mathrm{F}$ & $\begin{array}{l}\text { Sign. } \\
\text { level }\end{array}$ \\
\hline $\begin{array}{l}\text { Total } \\
\text { abundance } \\
\text { [long }(n+1)]\end{array}$ & $\begin{array}{l}\text { Among groups } \\
\text { Within groups } \\
\text { Total }\end{array}$ & $\begin{array}{r}3 \\
14 \\
17\end{array}$ & $\begin{array}{r}6032750.2 \\
5672119.8 \\
11704870.0\end{array}$ & $\begin{array}{r}2010916.7 \\
405151.4\end{array}$ & 4.96 & 0.014 \\
\hline $\begin{array}{l}\text { Total } \\
\text { biomass } \\
\text { [long }(n+1)]\end{array}$ & $\begin{array}{l}\text { Among groups } \\
\text { Within groups } \\
\text { Total }\end{array}$ & $\begin{array}{r}3 \\
14 \\
17\end{array}$ & $\begin{array}{r}425.291 \\
11877.153\end{array}$ & $\begin{array}{l}141.76370 \\
848.36810\end{array}$ & 0.167 & 0.916 \\
\hline
\end{tabular}




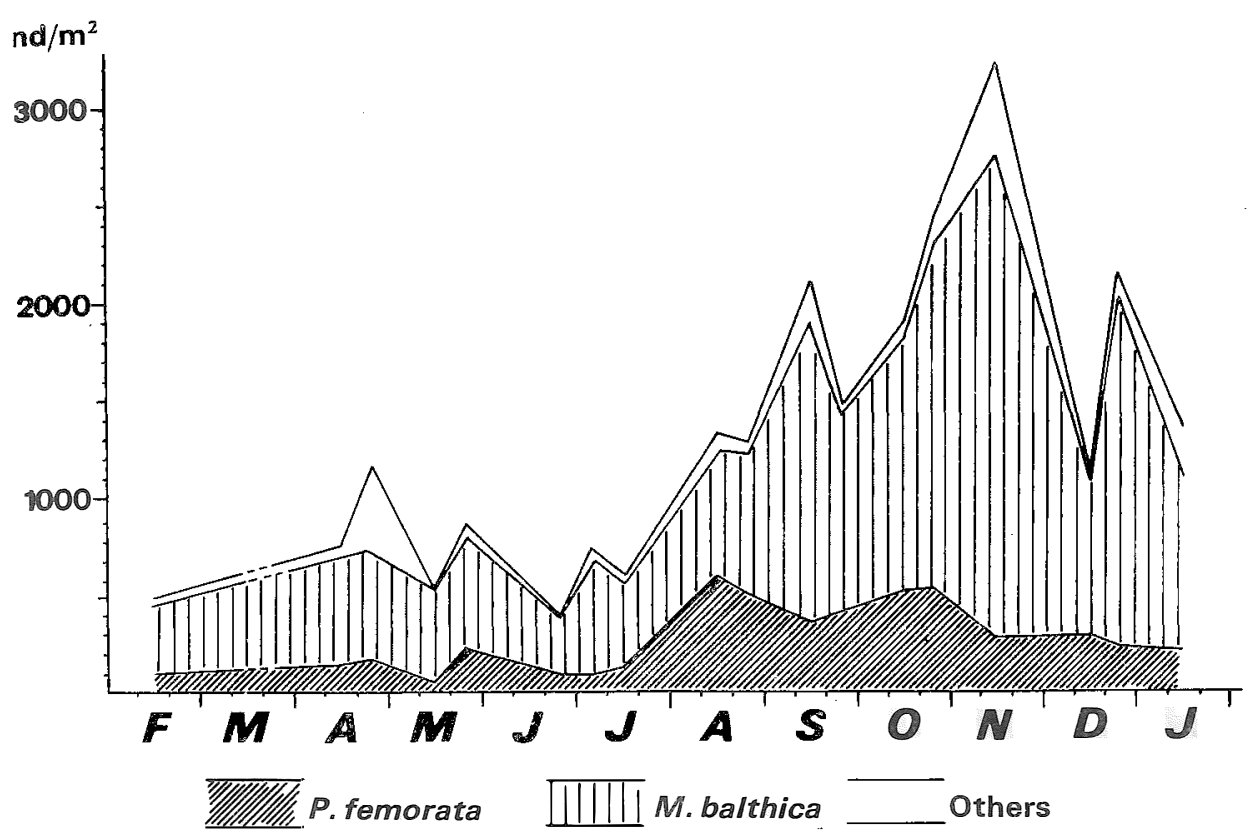

Fig. 2. Annual fluctuations in cumulative macrofauna abundance (ind $/ \mathrm{m}^{2}$ ) at the sampling station

The increase in abundance, observed from August until November resulted mainly from the increase in abundance of $M$. balthica and $P$. femorata after they had settled, as it can be seen from Figs 3 and 4. The presence of a young generation of $M$. balthica was observed throughout the year, with a maximum in October - December, while the appearance of young $P$. femorata was recorded in July - August. It seems, how ever, that the faunal abundances recorded contain a substantial error due to the fact that young macrofaunal specimens could not be quantitatively extracted with the $1 \mathrm{~mm}$ sieve used (Ankar 1976; 1980; Cederwall 1978). As can be seen in Figs 3 and 4 , the sieving technique applied failed to produce appropriate samples of those animals smaller than $2 \mathrm{~mm}$. It seems that the young generations of $M$. balthica and $\mathbb{P}$. femorato were recorded in macrofaunal samples some months after the recruitment. The zooplankton samples taken concurrently at the station visited showed the peak of larval M. balthica abundance to occur in May (Krajewska-Sołtys, in press), while the maximum of $M$. balthica in meiofaunal samples was recorded in July (Drgas, pers. comm.). These findings concur with the results of Ankar (1980) who found the highest number of newly settled recruits in late July. In the present work, an increased frequency of young specimes of $M$. balthica was not recorded until September. There is no information on settling of $\mathbb{P}$. femorate at the study site, but as indicated in the literature (Cederwall 1978; Ostrowski 1976; Segerstråle 1950), the release of the young occurs most probably in spring. 

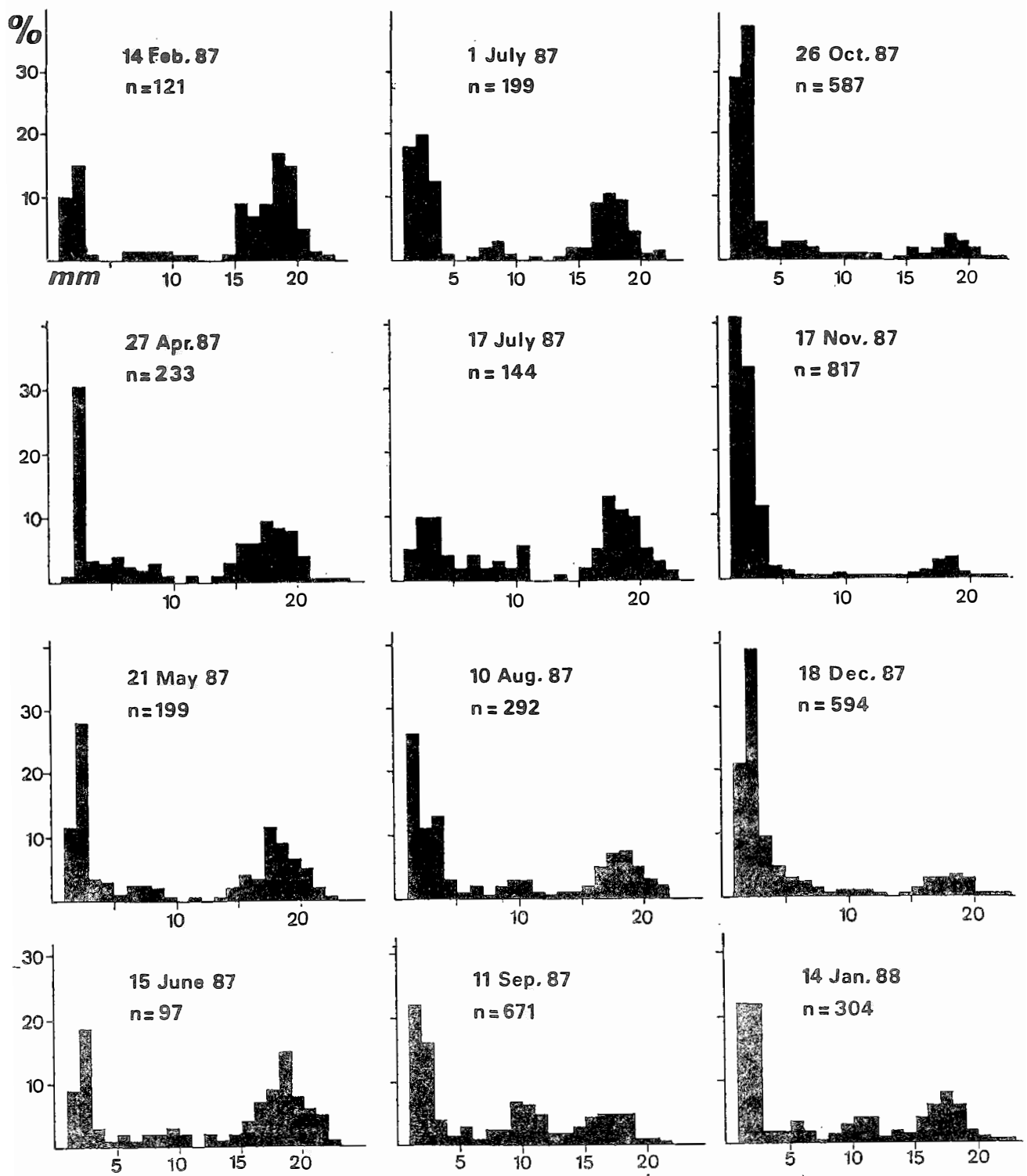

Fig. 3. Size-frequency distribution of Macome baltice from $35 \mathrm{~m}$ depth in the Gulf of Gdańsk, between Feb. 1977 and Jan. 1988 

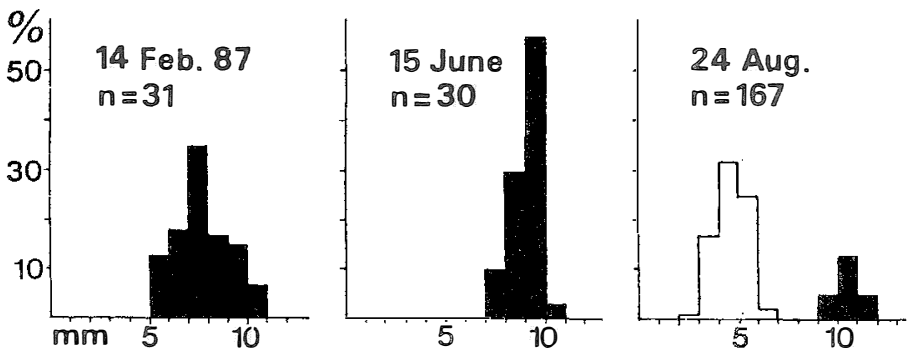

17 Nov.

$n=96$
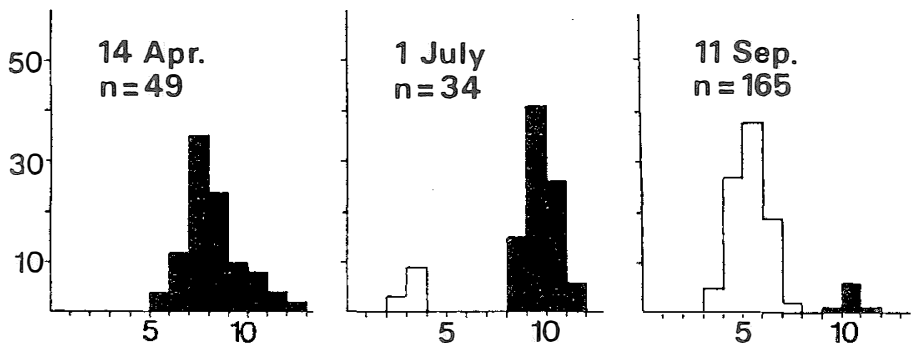

3 Dec.

$n=99$
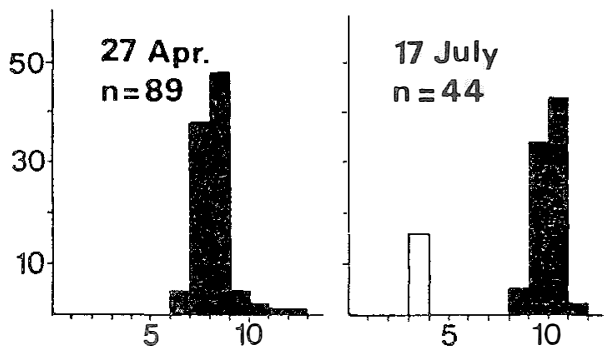

25 Sep.

$n=134$

18 Dec.

$n=82$
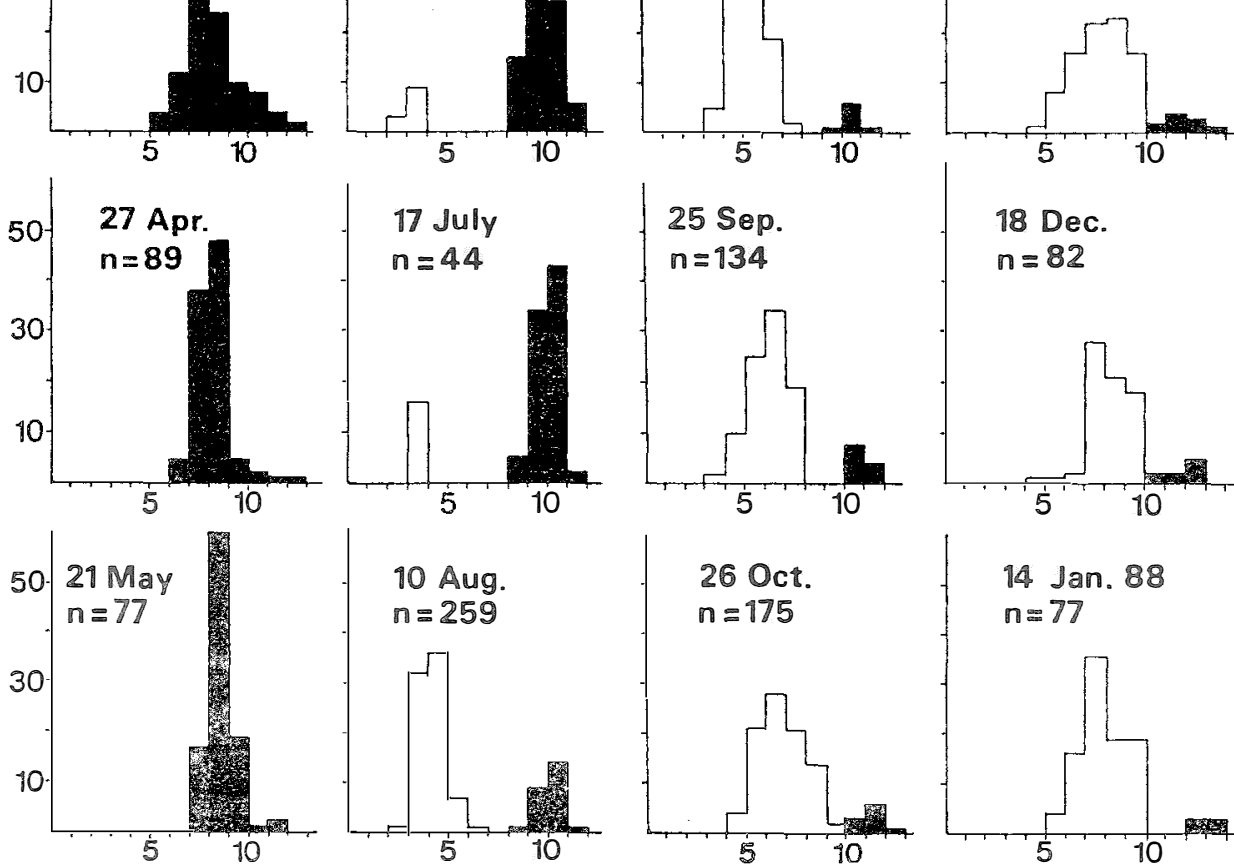

14 Jan. 88 $n=77$

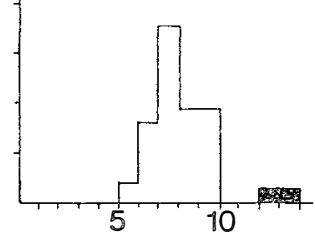

Fig. 4. Size-frequency distribution of Pontoporeia femorate from $35 \mathrm{~m}$. depth in the Gulf of Gdanssk, between Feb. 1977 and Jan. 1988. Shaded area denotes older $\left(1^{\dagger}\right)$ and blank area younger $\left(0^{\dagger}\right)$ generation

The absence of any significant changes in the total biomass (Table 2) throughout the year is related to domination of theilong-lived M. balthica (Fig. 5). Very similar biomass values were obtained in the area during earlier studies (Herra and Wiktor 1985; Warzocha 1985; Wenne and Wiktor 1982). Thus it may be concluded that the soit bottom macrofauna in the Gulf of Gdańsk shows a long-term stability. 


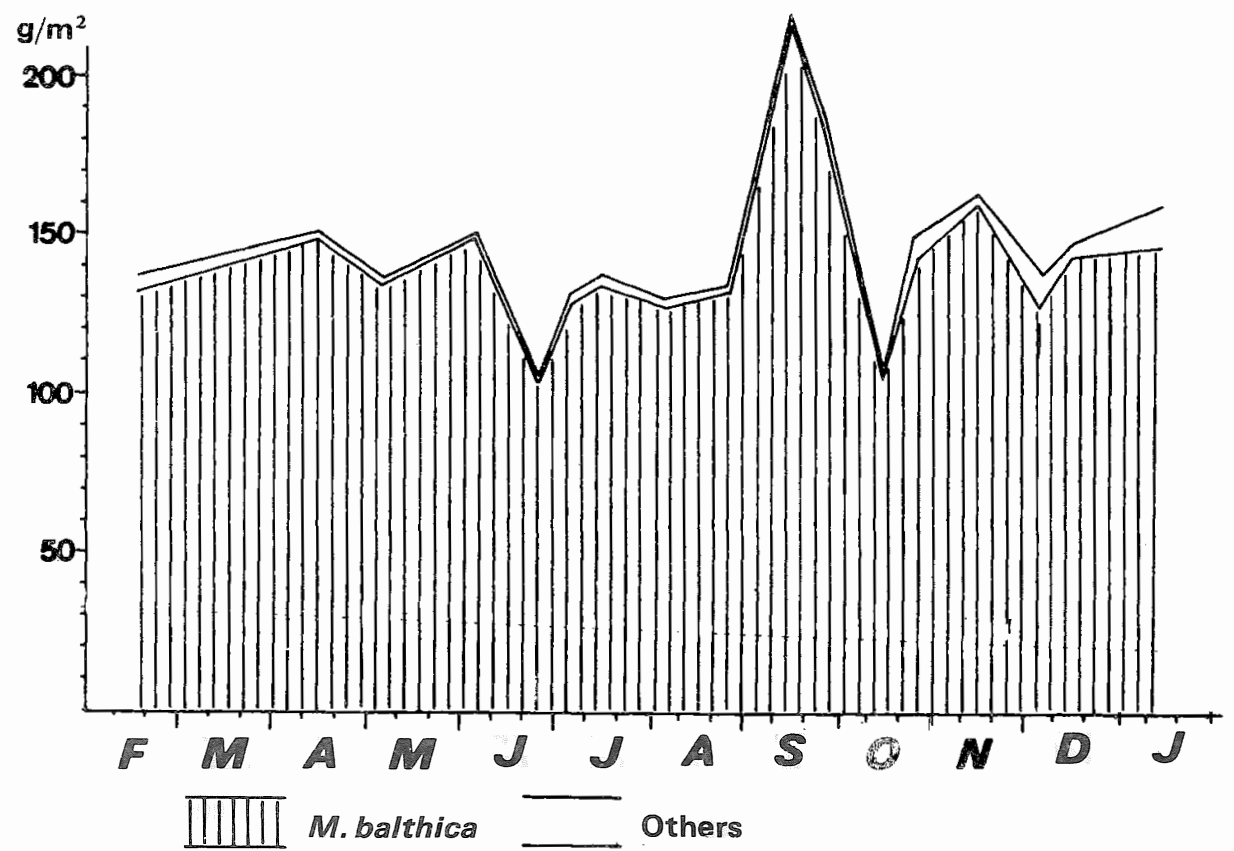

Fig. 5. Annual fluctuations of macrofauna biomass ( $\mathrm{g}$ dry weight, incl. shells of $M$. baltica $\mathrm{m}^{2}$ ) at the sampling station

Table 3 gives values of the annual production estimated for the species contributing more than $0.1 \%$ of the total biomass.

Table 3

Macrofauna production estimates for the Gulf of Gdańsk at $35 \mathrm{~m}$ station

\begin{tabular}{|l|c|c|c|c|}
\hline & \multicolumn{2}{|c|}{ Biomass } & \multicolumn{2}{c|}{ Estimated Annual Production } \\
\cline { 2 - 5 } & $\begin{array}{c}\text { shell-free } \\
\left(\text { d.w. } / \mathrm{m}^{2}\right)\end{array}$ & $\begin{array}{c}\text { Energy } \\
\left(\mathrm{KJ} / \mathrm{m}^{2}\right)\end{array}$ & $\begin{array}{c}\text { shell-free } \\
\left(\mathrm{d} . \mathrm{w} . \mathrm{g} / \mathrm{rn}^{2}\right)\end{array}$ & $\begin{array}{c}\text { Energy } \\
\left(\mathrm{KJ} / \mathrm{m}^{2}\right)\end{array}$ \\
\hline H. spinulosus & 0.35 & 8.40 & 0.32 & 7.56 \\
H. entomon & 2.03 & 3.11 & 2.13 & 3.27 \\
P. femorete & 0.52 & 7.96 & 0.73 & 11.14 \\
M. balthica & 25.70 & 484.45 & 10.28 & 193.78 \\
\hline Total & 28.60 & 503.92 & 13.46 & 215.75 \\
\hline
\end{tabular}


Production of $M$. balthica and $\mathbb{P}$. femorata was calculatedl using $\mathrm{P} / \mathrm{B}$ ratios of 0.37 and 1.40, respectively, following Ostrowski (1976). For $H$. spinulosus, an annual $P / B$ ratio of 0.9 (Arntz 1971) and for M. entomon, the life cycle turnover ratio of 3.5 (Waters 1969 ) and 0.3 generations per year (Ankar and Elmgren 1976) were assumed.

The total annual production of macrofauna is roughly estimated at $215.75 \mathrm{KJ} / \mathrm{m}^{2}$, which is probably an underestimate since the $P / B$ ratios for the two dominant species (M. balthica and $P$. femorata) given by Ostrowski (1976) were calculated based on the materials sieved through a $1.0 \mathrm{~mm}$ mesh size sieve.

\section{REFERENCES}

Ankar S., 1976: Final report from the benthic macrofauna group. Baltic Sea expert meeting on intercalibration of biological and chemical methods. Contr. Askö Lab., 12, 27 pp.

Ankar S., 1980: Growth and production of Macoma balthica (L.) in a northern Baltic soft bottom. Ophelia, 1: 32-48.

Ankar S., R. Elmgren, 1976: The benthic macro- and meiofauna of the Askö-Landsort area (Northern Baltic Proper). Contr. Askö Lab., 11, 115 pp.

Amtz W.G., 1971: Biomasse und Produktion des Makrobentos in den tieferen Teilen der Kieler Bucht im Jahr 1968. Kieler Meeresforsch., 25: 36-72.

Brey T., H. Rumohr, S. Ankar, 1988: Energy content of macrobenthic invertebrates: general conversion factors from weight to energy. J. exp. mar. Biol. Ecol., 117: 271-278.

Cederwall H., 1978: Long term fluctuations in the macrofauna of northern Baltic soft bottoms. I. 1970-1973. Contr. Askö Lab., 22, 83 pp.

Herra T., K. Wilktor, 1985: Skład i rozmieszczenie fauny dennej w strefie przybrzeżnej Zatoki Gdańskiej właściwej. Stud. Mat. Oceanolog., 46: 116-142.

Kopacz M., K. Wiktor, 1986: Some aspects of the biology of Mesidotea entomon in the Gulf of Gdańsk. Ophelia, Suppl. 4: 111-117.

Krajewska-Soltys A., (in press): Sezonowe zmiany biomasy metazooplanktonu na stacji 92A (Zatoka Gdańska) w 1987 roku. Biul. MIR.

Ostrowski J., 1976: Biomass and production of the crustacean Pontoporeia femorata and bivalve Mocoma balthica (Linne) in the Gulf of Gdańsk. Prace MIR Gdyni, 18A: 81-94.

Pielou E.C., 1975: Ecological Diversity. Wiley Interscience, New York.

Segerstråle S.G., 1950: The amphipods on the coast of Finland - some facts and problems. Comm. Biol., 10, $28 \mathrm{pp}$.

Sokal R.R., F.J. Rohlf, 1981: Biometry. Freeman and Co., San Francisco.

Waters T.F., 1989: The turnover ratio in production ecology of freshwater invertebrates. Am. Natur., 103; 173-185.

Warzocha J., 1982: Structure of benthic macrofauna communities in the Gulf of Gdańsk. ICES C.M. 1982/L: 58.

Warzocha J., 1987: Classification and community structure of macrofauna in the southern Baltic. ICES C.M. 1987/L:8.

Wenne R., K. Wiktor, 1982: Fauna denna przybrzeżnych wód Zatoki Gdańskiej. Stud. Mat. Oceanolog., 39: 139-170.

Żmudzin̊ski L., 1966: Baltic - Belt Seas seasonal migrations of coldwater fauna in the Gdańsk Bay. Ann. Biol., 21: $65-67$.

Author's address:

Sea Fisheries Institute

ul. Kołłątaja 1

Gdynia, Poland 